\title{
Nomadland: The New Frontiers of the American Dream at the Periphery of the Market
}

\author{
Aleksandrina Atanasova \\ University of Birmingham, Birmingham, UK \\ Giana Eckhardt \\ King's Business School, King's College London
}

Follow this and additional works at: https://digitalcommons.uri.edu/mgdr

Part of the American Film Studies Commons, American Material Culture Commons, Anthropology Commons, Business Law, Public Responsibility, and Ethics Commons, Economics Commons, Film and Media Studies Commons, Geography Commons, Marketing Commons, Other Business Commons, Real Estate Commons, and the Sociology Commons

\section{Recommended Citation}

Atanasova, Aleksandrina and Eckhardt, Giana (2021) "Nomadland: The New Frontiers of the American Dream at the Periphery of the Market," Markets, Globalization \& Development Review. Vol. 6: No. 1, Article 2.

DOI: $10.23860 / M G D R-2021-06-01-02$

Available at: https://digitalcommons.uri.edu/mgdr/vol6/iss1/2

This Dialogue is brought to you for free and open access by DigitalCommons@URI. It has been accepted for inclusion in Markets, Globalization \& Development Review by an authorized editor of DigitalCommons@URI. For more information, please contact digitalcommons-group@uri.edu. 
Nomadland: The New Frontiers of the American Dream at the Periphery of the Market

\section{Markets, Globalization \& Development Review}
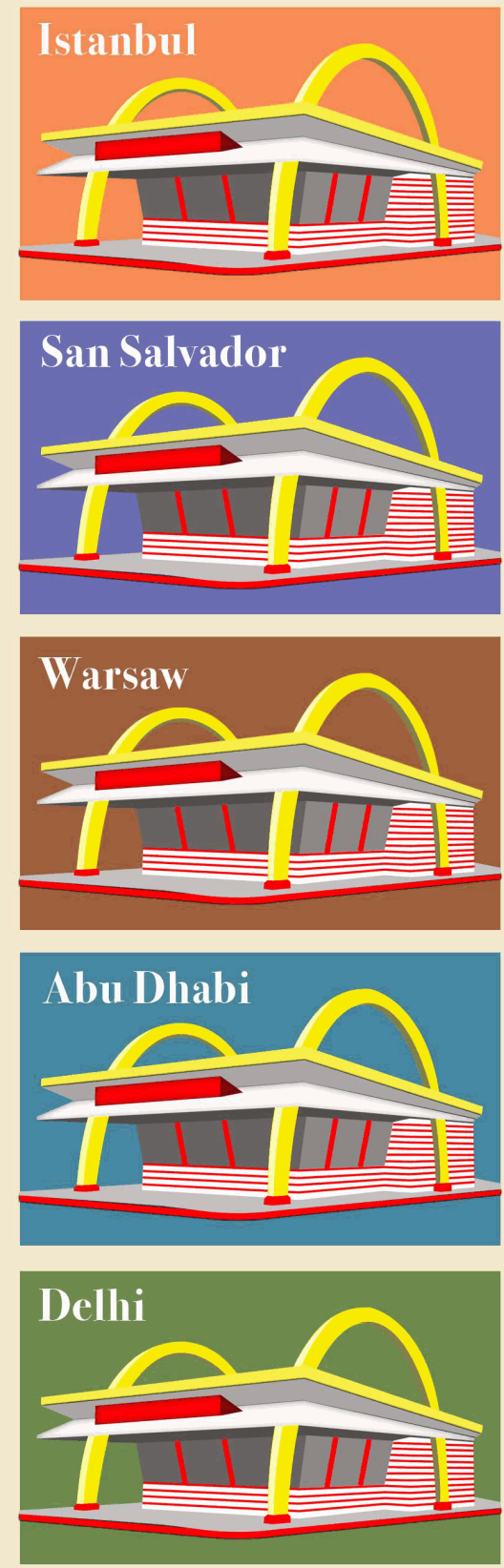
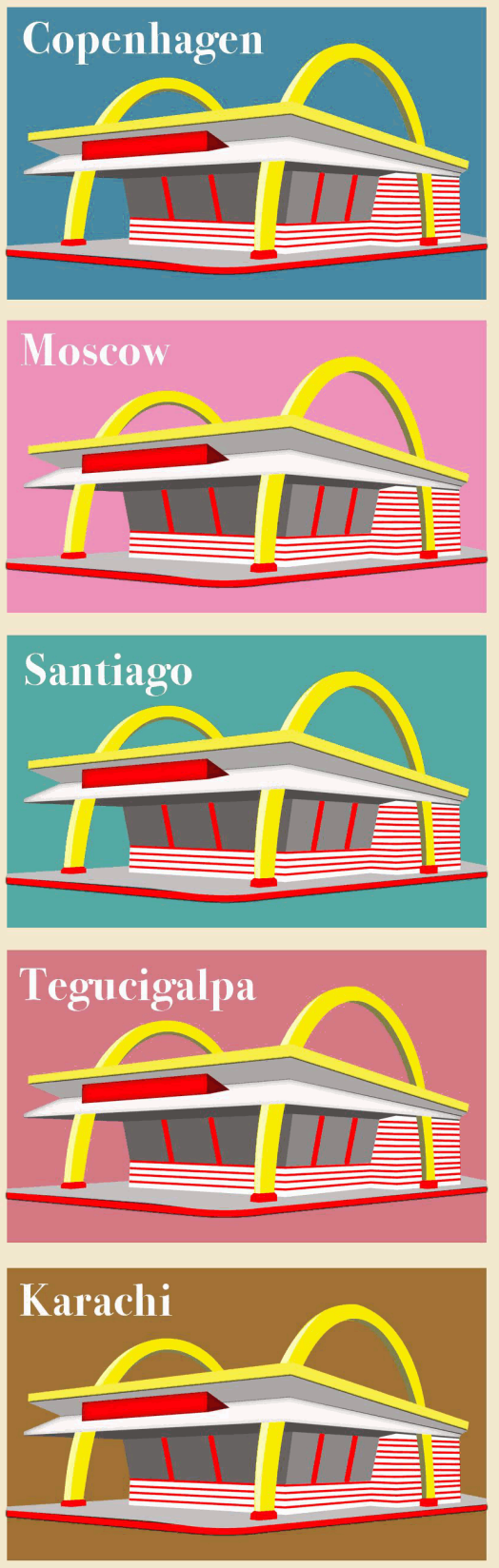
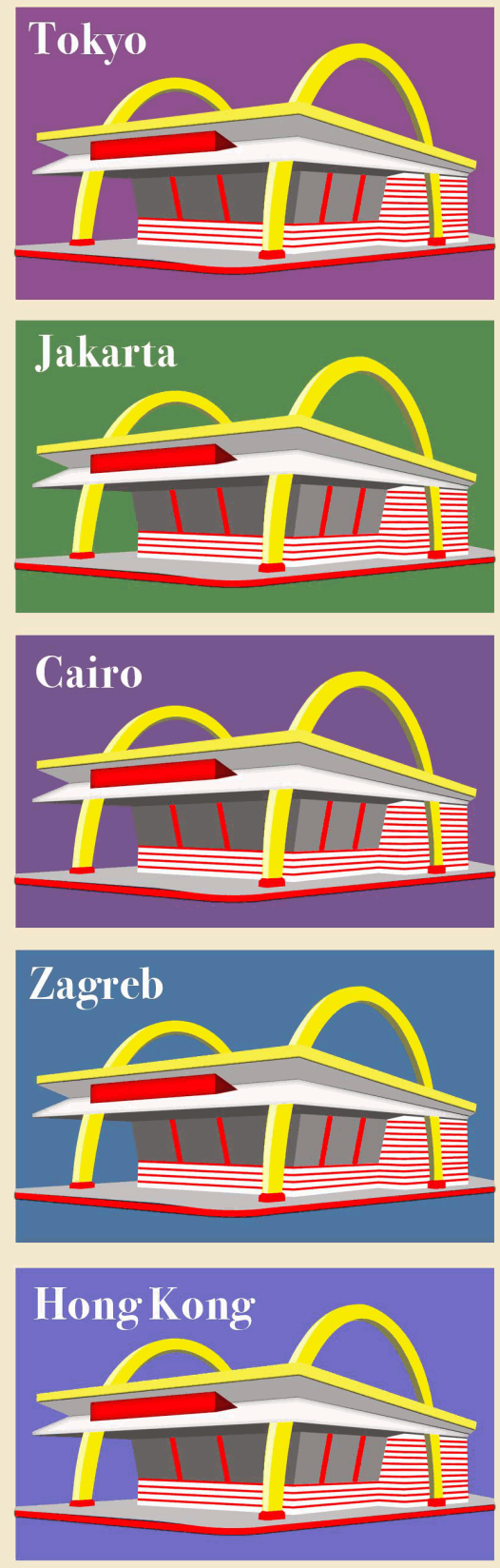

This dialogue is available in Markets, Globalization \& Development Review: https://digitalcommons.uri.edu/mgdr/ vol6/iss $1 / 2$ 


\section{Nomadland: The New Frontiers of the American Dream at the Periphery of the Market}

"I am not homeless. I am just houseless. Not the same thing, right?" (Fern 9:55)

\section{Introduction}

It is a cold winter day in Nevada, sometime in late 2011, not long after the ghost town of Empire lost its zip code. Residents have fled since the gypsum mine that sustained the community shut down as a casualty of the Great Recession. A woman sifts through possessions that have been hastily thrown in a storage unit. She places a box of old dishes wrapped in newspaper in the back of a van to take with her. Other possessions, such as a box of men's clothes, which she clutches overcome with grief and sorrow, will stay. So begins the story of Fern, a 61-year-old widow who has lost everything - her home, her husband, and the life that she has known - and begins living in a van, travelling through the American west, searching for work.

Nomadland (2020), adapted from Jessica Bruder's (2017) nonfiction book Nomadland: Surviving America in the Twenty-first Century (2017), was one of the most critically acclaimed films of 2020/1. Situated in the aftermath of the economic collapse of 2007-2009, the film offers a portrait of a growing community of older Americans who, forced out of the workforce or facing insufficient social security checks and lack of retirement savings, live nomadically in vans, chasing after low-wage jobs for a chance to make ends meet. In 2021, the film collected three Academy awards, alongside a long list of other accolades, including Golden Globes and BAFTAs. Since its release, viewers and critics alike have been captivated by the film's poignant tale of grief, resilience, desperation, and hope, all blending together in the life stories of these unlikely new American nomads: 55+ year-olds, once middle-class, now "workcampers," whose golden years are spent chasing back-breaking temporary work around the country, living with few possessions and sleeping in makeshift homes on wheels. Not in RVs, which are designed to be lived in, but regular vans, jerry-rigged with the bare minimum to make them habitable, like buckets for going to the bathroom.

Dubbed the modern Grapes of Wrath (Steinbeck 2017: 1939), in many ways, Nomadland is a familiar story of the search for a better life in 
the face of despair, where the role of the solitary hero is romanticized. It is also, however, a novel story of the dystopian economic dispossession of an aging population for whom retirement is an out-of-reach illusion (Brooks 2021; Bruder 2014). In this Dialogue contribution, we explore the complex portrait of these nomads as consumers and the role of the globalized marketplace in their lives as portrayed in the film and beyond.

\section{The Tyranny of the Marketplace}

The emotional gravitas of the film slowly emerges, as the viewer follows Fern, one of the few fictional characters among a cast of many real-life nomads, as she upends her life and becomes nomadic after losing her husband to cancer, and her job and her savings to the Great Recession. Down the road, as Fern finds her footing in this new way of life that is both challenging and liberating, she crosses paths with Linda May and Charlene Swankie, real-life nomads who are central figures in Bruder's book and who play themselves in the movie, sharing the stories of precarity and struggle from their biographies. As the film unfolds, we meet other real nomads, such as Bob Wells - a well-known van dweller who runs the popular Cheap RV Living YouTube channel and is the president of a non-profit he founded, Home on Wheels Alliance (Paiella 2021). In real life, Wells is considered to be the guru of van dwelling, having inspired and guided an entire generation of economically precarious elderly folks to find an alternative path in life. His celebrity status is easy to notice in the movie, as the nomads are visibly engaged while he speaks at the Rubber Tramp Rendezvous events that he organizes, which take place each year in Arizona and attract thousands of van dwellers. Sharing various tips, which he labels "commandments" (e.g., "10 commandments for how to stealth-park"), Wells has a single purpose: to offer know-how to those "who need help now" - the outcasts of the modern capitalistic machine, left to fend for themselves on meager social security. In one scene, Wells offers a candid description of the broader socioeconomic conditions that have led to the necessity of van dwelling as a way of life:

"And the odd thing is that we not only accept the tyranny of the dollar, the tyranny of the marketplace, we embrace it. We gladly throw the yoke of the tyranny of the dollar on and live by it our whole lives. The way I see it is that the Titanic is sinking, and economic times are changing. And so, my goal is to get the lifeboats out and get as many people into the lifeboats as I can." (Bob 18:30). 
It is against this backdrop that Nomadland offers a critical vantage point on the new frontiers of the American Dream. A dream which for these nomads is a seasonal job and a functioning van, rather than a house filled with material possessions. In times of hardship and uncertainty, the utopian impulse to escape to a better place intensifies (Bauman 2007). Nomadland, however, portrays a reorientation from utopian dreams for abundance and permanence to a nomadic utopian imaginary, where the desire for a better way of living and being is materialized through emancipation from normative life trajectories. This is a reorientation that is part of a larger shift in the social imaginary from solid to liquid utopian thinking, where the only way to devise betterment is in transient, individually pursued, and short-lived moments of envisioning and enacting life in the present, rather than pursuing collective, long-term change in the future (Atanasova 2021). Even though they have worked their whole lives chasing after an idealistic aspiration of what the good life looks like, these nomads cannot afford to get there. The promises of the marketplace are far out of reach - either because of illness, or overwork in unfulfilling corporate jobs, or simply lack of stable employment. Nomadic living thus emerges as a liberatory act of emancipation from the tyrannic marketplace, imbued in an ideology of self-sufficiency and empowerment - values which have and continue to propel individuals toward achieving the American Dream, albeit this time a precarious one.

\section{Consuming and Being Consumed}

As consumers, these nomads are portrayed at the periphery of the marketplace - consuming little and, when they do, mostly bartering, where one nomad's discarded possessions become another nomad's treasure. Still, it is easy to see that this minimalism is a learned behavior out of necessity. Fern, Linda May and Swankie all laugh when they see that the expensive, brand-new RVs, which they sit in just to experience what life with money would feel like, have washers and dryers - symbols of domestic comfort they have long parted with. Fern and her companions are often seen trying to re-create what would be hedonic consumption episodes. For example, as Fern meets the New Year alone in her van, eating a modest meal, she wears a "Happy New Year" tiara on her head in an attempt to normalize the moment and link it to familiar consumption practices and artifacts. Such moments of connect and disconnect with the normative affordances of the marketplace are abundant in the movie. In another scene, Fern is organizing a spa moment for Linda May and herself; after a hard day's work cleaning a campground, they playfully lounge on camp chairs with cucumbers over their eyes and self-made 
moisturizing sheets over their faces. Such scenes remind us that despite the liberatory cloak over nomadism and the portrayed romanticization of living with little (e.g., showing pride in having repurposed old items to be functional in a small space), these nomads long for the hedonic consumption their precarity has denied them. As Atanasova and Eckhardt (2021) point out, even in the absence of ownership, materialistic logics of consumption persist.

The film also offers a delicately crafted portrait of the paradoxical interdependence between the marketplace and those for whom the marketplace is out of reach. Working long hours on the hard concrete floors of places like fast-food restaurants, factories, and Amazon warehouses, these nomads are portrayed as essential workers who, with their hard and cheap labor, sustain big business. Amazon, for instance, has a prominent presence in the film, as Fern works there alongside other nomads as part of the Amazon's "CamperForce" - a temporary workforce mostly comprised of poor elderly nomads that is mobilized during the holiday season only to be quickly disposed of after. Amazon provides free parking space for the vans and pays what Fern describes as "great money" (8:50) (up to $\$ 18.05 /$ hour depending on location, per Amazon's own website https://www.amazondelivers.jobs/about/camperforce/). The 'tyranny of the marketplace' is easy to discern as Fern is shown packing numerous boxes filled with holiday gifts on the last day of the season, New Year's Eve. With the end of the busy holiday season comes the end of her employment. She retreats to her van to meet the new year ill with a cold, and alone, her paid-for parking spot to expire in a few days. The implied wastefulness of consumerism seeps through the images of the numerous Amazon boxes as Fern works her last shift and is easy to perceive through the contrast with Fern's precarious life outside of the warehouse. Amazon is portrayed as both savior to and exploiter of these nomads. A behemoth that has transformed virtually all corners of the marketplace (Kahn and Hamilton 2019), Amazon has not only monopolized the consumption behaviors of the masses, but also the elderly years of the economically precarious and their bodies as workers.

\section{Possessions and Materiality}

Nomadland offers a gripping image of what life looks like in the absence of solidity and material possessions. With everything solid and stable in her life gone, Fern creates a micro-world in her van, maximizing every inch of it for the greatest utility the space can offer. Everything in the van has a high use-value and has a purpose. Still, many of her minimal possessions are imbued with meaning. In the first half of the film, Fern's possessions 
are depicted as extensions of her identity and means to create meaning in migration (Belk 1992; Peñaloza 1994) that sustains her symbolic connection with her roots and past life. For instance, we learn that the old dishes she packed in the opening scene have been given to her by her father; yet, as her nomad friend and possible romantic interest accidentally breaks them, the impracticality of such possessions as carriers of emotional value is easily seen. As Fern becomes more comfortable with her nomadism, the emotional distance between her present life and her past widens, and her relationship with her possessions liquifies, becoming characterized by detachment and flexibility (Bardhi, Eckhardt and Arnould 2012).

At the very end of the movie, Fern returns to Empire. Back in front of the garage that holds all her possessions, she meets with the man who runs the storage unit. This time, his pick-up truck is loaded with her things, not her van. "Are you sure you don't need any of this stuff?," he asks. "No, I don't need any of it. I'm good," Fern replies, "I'm not going to miss one thing" (1:38:48). At this point, her possessions are no longer an integral part of her self-identity, and the loss of these possessions is not felt as the violation of herself (Belk 1988) that she experienced earlier when her beloved plates got broken. As has been shown in consumer research on the meaning of possessions for the homeless (Hill and Stamey 1990), the lack of material objects is compensated with processes of self-restoration that entail perceptual changes in the interpretation of what a "home" should be in a physical sense. Early in the film when asked if she is homeless, Fern replies assertively that she is not homeless, but houseless (9:55). And a co-worker at Amazon shows Fern her tattoo, which says, 'home is what you carry with you.' This arc in the narrative comes full circle as we see Fern, in the last minutes of the film, visiting her former house, now empty, deserted, and void of meaning, not to reminisce but to part with it for good. With her possessions gone, and her worldview as a consumer re-oriented toward flexibility and detachment, rather than permanence and rootedness (Bardhi and Eckhardt 2017), the viewer is at last convinced that she is houseless, not homeless, and that there is indeed an important difference.

\section{Nomadism as a Way of Modern Life}

From a sociocultural point of view, nomadic ways of life, subject to logics of detachment and impermanence, are often stigmatized. Nomads have traditionally been perceived as a "wandering threat," challenging the established ordering of life, shattering classifications, and occupying undefined spaces where along the way they embrace difference and 
resistance (Engebrigsten 2017). In the wake of widespread digitalization and globalization, however, mobility has become an underlying feature of the contemporary experience. Nomadland brings to the forefront the growing prominence of nomadic living at the intercept of precarity and insecurity. While the elderly nomads in the movie are at the periphery due to their economic precarity, other generations such as Millennials and Gen-Zs are not spared from the looming insecurity of the present moment. Digital nomadism, for instance, is emerging as an increasingly popular lifestyle among large cohorts of consumers who are facing an overarching sense of discontent with normative life in the context of omnipresent insecurity and seek ways to renegotiate their position within the global market economy (Atanasova and Eckhardt 2021; Woldoff and Litchfield 2021). Digital nomads are people who travel with minimal possessions around the world while working from their laptops, taking their jobs with them wherever they go (see Mancinelli 2020; Woldoff and Litchfield 2021). While they do not make a living through manual labor, as do the van dwellers in Nomadland, but through work done in the digital space, many of them are no less precarious as they roam between inexpensive locations around the world, trying to maximize their incomes that, in major cities, cannot afford them the lives they wish to lead (Atanasova and Eckhardt 2021; Woldoff and Litchfield 2021).

Other, more "conventional" workers have also begun to move towards digitally nomadic set-ups, choosing to work from beach cottages, forest cabins and suburban houses outside expensive city centers (Lufkin 2021), a trend which has intensified during the normalization of 'working from home' amid the ongoing covid pandemic. There is much to suggest that for many, nomadism is becoming a means for escaping the bleak present reality and pursuing better ways of being in the world (Atanasova 2021). For example, Fern has multiple opportunities to give up her nomadic life in the movie. Her potential romantic partner invites her to move in with him at his son's house, and Fern's sister invites her to move in with her. Despite the privations of van dwelling, Fern ultimately finds a solidarity in living within the nomadic community and sees it as a way to protest against a way of life that is no longer sustainable in contemporary America. Fern articulates this when she is at her sister's house and speaking with her brother-in-law, who is a real estate agent, and says, "Real estate makes people buy houses they can't afford" (Fern, 1:13:18). Ultimately, Fern chooses a life, however precarious, which allows her to live without being mired in the stress that come with living a life one cannot afford, a reality for more and more people within the United States. 


\section{Precarity, Mobility, Liquidity in Global Settings}

Going beyond this film, it is useful to reflect briefly on these issues in the wider global setting. We are witnessing an inflection point in the modern lived experience where universal precarity and loss of hope in the future have become prominent features of the sociocultural landscape (Beck 1986; Berlant 2011; Lorey 2015). What used to be enduring and solid structures and traditions are increasingly being replaced by their ephemeral, liquid alternatives (Bauman 2000; 2007). While they can be liberating for some, they are also challenging to manage (Bardhi and Eckhardt 2017), giving individuals no choice but to be on the move to cope with the fluid logics of contemporary life. In this liquid modernity, defined by ambivalence (Bauman 2000), mobility is relational to new emergent forms of power and inequality. In today's global world, mobility might be omnipresent, yet not all on the move are equal; some are "tourists," effortlessly able to travel light and pursue opportunities, and others are "vagabonds," moving out of necessity (Bauman 2000). Against this backdrop, consumers are being pushed to part with traditional ideals and familiar ways life and to seek alternative forms of security and legitimation in an act of detachment from conventional and illusionary fantasies of the American dream that are quickly dissolving in the "landfill for overwhelming and impending crises of life-building" (Berlant 2011:3).

While Nomadland is clearly a story about the vagabonds of liquidity who have no other choice but to embrace mobility, it reminds us that many nomads choose to detach from rootedness and solidity to escape the dead-end trajectory of conventional life surrendered to capitalistic and materialistic logics. As shown in the film, this is true for many of the elderly nomads who jump into the lifeboats of nomadic living to escape unfulfilling corporate jobs and the 'tyranny of the dollar.' It is also true for the growing cohorts of digital nomads (Atanasova and Eckhardt 2021; Mancinelli 2020), many of whom seek to circumvent the same woes of modern life. In a globalized world, however, true freedom inheres in the ability to evade the limitations and economic implications of geography. Digital nomads do so by living seemingly luxurious and abundant lives in countries with cheaper costs of living where they can afford to work less hours (Atanasova et al. forthcoming; Woldoff and Litchfield 2021). These digital nomads are tourists on the global stage, wandering about free, capitalizing on various forms of privilege (Atanasova et al. forthcoming, Mancinelli 2020). Yet, similar to the elderly in Nomadland, these digital nomads have left the 9-to-5 office life because they cannot see themselves ever able to own a home or afford to retire, and do not want to toil as office drones for the rest of their working lives (Woldoff and Litchfield 2021). The precarious 
elderly in Nomadland roam desperately searching for whatever job can allow them to stretch to the end of the month. Still, however precarious their nomadic living might be, through it, they too, along with digital nomads, seem to find freedom and solidarity outside of a normative, settled life, where rootedness is increasingly out of reach and mobility is redefining social structuration. The rising prominence of nomadic living foregrounds that globalization is not only an 'out there' phenomenon, farremoved from the individual, but also an 'in here' phenomenon that influences the most personal aspects of life (Gane 2001; Giddens 1994).

\section{Concluding Comments}

Nomadland is unambiguous in its depiction of modern-day nomadism as both a choice for some and inevitability for others. Regardless of one's entry point to this way of life, however, nomadic living is built around tradeoffs: conventional comforts for a better chance at making ends meet; material possessions for finding meaning in oneself, not the things one owns. As one Rubber Tramp Rendezvous leader says, "I love this lifestyle. It is a lifestyle of freedom, and beauty, and connection to the Earth. Yet there is a trade-off. You got to learn how to take care of your own $\mathrm{s}^{* *}$ t." (25:00). In many ways, Nomadland is an ode to the resistance of dominant market logics of accumulation and ownership. Although at the periphery of the marketplace, however, nomadic life is also a life that is increasingly commodified through YouTube channels, how-to-guides, and blogs. Navigating between the extremes of lack and social displacement, and community and newfound ability to live life with little, the nomads in Nomadland and the many others like them are thus finding ways to carve a new path in the face of despair and disenchantment. Nomadland is ultimately a critique of the death of the American dream at the hands of Amazon and similar behemoths, while at the same time a story of solidarity amongst the dispossessed who have taken a chance on bucking the system and living with a sense of freedom at the end of their lives.

In today's global economy of intermittent and flexible labor regimes, not just the traditionally poor, but also the middle class are dwelling on the periphery (Han 2018). Against this backdrop, for many, true nomadic living emerges as the only viable path to stability in a globalized world long detached from bounded logics of stasis and rootedness. Reflecting on the average white-collar worker who, in a liquid world that demands mobility and flexibility, is tethered to their cubicle, one might wonder, who are the vagabonds, the suffering victims of the global economic system, and who are the privileged tourists? Perhaps it is the nomads at large who have figured out how to manage in a post-home ownership, post-American 
dream landscape, who are able to be one step closer to horizons of opportunity through their mobility. 


\section{References}

Atanasova, Aleksandrina (2021), "Re-Examining Utopia in Contemporary Consumption: Conceptualization and Implications for Marketing," AMS Review, 11 (1-2), 23-39. https://doi.org/10.1007/s13162-021-00193-0

Atanasova, Aleksandrina and Giana M. Eckhardt (2021), "The Broadening Boundaries of Materialism," Marketing Theory, May. https://doi.org/10.1177/14705931211019077

Atanasova, Aleksandrina, Fleura Bardhi, Giana M. Eckhardt and Laetitia Mimoun (forthcoming), "Digital Nomadism as Temporal Privilege," The Routledge Handbook of Digital Consumption, eds. Russ Belk \& Rosa Llamas, Routledge.

Bardhi, Fleura and Giana M. Eckhardt (2017), "Liquid Consumption," Journal of Consumer Research, 44 (3), 582-97. https://doi.org/10.1093/jcr/ucx050

Bardhi, Fleura, Giana M. Eckhardt, and Eric J. Arnould (2012), "Liquid Relationship to Possessions," Journal of Consumer Research, 39 (3), 510-29. https://doi.org/10.1086/664037

Bauman, Zygmunt (2000), Liquid Modernity, Cambridge, England: Polity.

Bauman, Zygmunt (2007), Liquid Times: Living in an Age of Uncertainty, Cambridge, England: Polity.

Belk, Russell W. (1988), "Possessions and the Extended Self," Journal of Consumer Research 15 (2), 139-68. https://doi.org/10.1086/209154

Belk, Russell W. (1992), "Moving Possessions: An Analysis Based on Personal Documents from the 1847-1869 Mormon Migration," Journal of Consumer Research, 19 (December), 339-61. https://doi.org/10.1086/209306

Berlant, Lauren (2011), Cruel Optimism, Duke University Press.

Brooks, Xan (2021), 'It's an Utter Myth': How Nomadland Exposes the Cult of the Western," The Guardian, April 9, (accessed on August 21, 2021), [available at: https://www.theguardian.com/film/2021/apr/09/itsan-utter-myth-how-nomadland-exposes-the-cult-of-the-western]

Bruder, Jessica (2014), "The End of Retirement," Harper's Magazine, (accessed on August 21, 2021), [available at: https://harpers.org/archive/2014/08/the-end-of-retirement/]

Bruder, Jessica (2017), Nomadland: Surviving America in the Twenty-first Century, Norton \& Company, NY.

Engebrigtsen, Ada Ingrid (2017), "Key Figure of Mobility: The Nomad," Social Anthropology, 25 (1), 42-54. https://doi.org/10.1111/1469-8676.1237 
Gane, Nicholas (2001), "Chasing the 'Runaway World': The Politics of Recent Globalization Theory," Acta Sociologica, 44 (1), 81-89. https://doi.org/10.1177/000169930104400107

Giddens, Anthony (1994), "Living in a Post-Traditional Society," in Reflexive Modernization: Politics, Tradition and Aesthetics in the Modern Social Order, Ulrich Beck, Anthony Giddens, and Scott Lash eds. Cambridge, England: Polity, 56-109.

Han, Clara (2018), "Precarity, Precariousness, and Vulnerability," Annual Review of Anthropology, (47), 331-43. https://doi.org/10.1146/annurev-anthro-102116-041644

Hill, Ronald Paul and Mark Stamey (1990), "The Homeless in America: An Examination of Possessions and Consumption Behaviors," Journal of Consumer Research, 17 (3), 303-21. https://doi.org/10.1086/208559

Kahn, Barbara and Ryan Hamilton (2019), "Is Amazon Getting Too Big?", Knowledge@Wharton, May 20, (accessed on August 21, 2021), [available at: https://knowledge.wharton.upenn.edu/article/amazon-too$\underline{\text { big/] }}$

Lorey, Isabell (2015), State of Insecurity: Government of the Precarious, London: Verso.

Lufkin, Bryan (2021), "Is the Great Digital-nomad Workforce Actually Coming?," BBC, (accessed on August 21, 2021), [available at: https://www.bbc.com/worklife/article/20210615-is-the-great-digitalnomad-workforce-actually-coming]

Mancinelli, Fabiola (2020), "Digital Nomads: Freedom, Responsibility and the Neoliberal Order," Information Technology \& Tourism, 22 (3), 41737. https://doi.org/10.1007/s40558-020-00174-2

Nomadland (2020), Director: Chloé Zhao. Writer: Chloé Zhao. Distributed by Searchlight Pictures, Sept. 11.

Paiella, Gabriella (2021), "Talking to One of the Real-Life Nomads of Nomadland", GQ, May 1, (accessed on August 21, 2021), [available at: https://www.gq-magazine.co.uk/culture/article/nomadland-interview]

Peñaloza, Lisa (1994), "Atraversando Fronteras/Border Crossings: A Critical Ethnographic Study of Consumer Acculturation of Mexican Immigrants," Journal of Consumer Research, 21 (March), 32-53. https://doi.org/10.1086/209381

Steinbeck, John (2017), The Grapes of Wrath, Harlow, England: Penguin Books.

Woldoff, Rachael A. and Robert C. Litchfield (2021), Digital Nomads: In Search of Freedom, Community, and Meaningful Work in the New Economy, New York: Oxford University Press. 